A suggested list is : Harvey's "De Motu Cordis" (1628); Galileo's "Dialogue concerning the Two Chief World Systems" (1632), selections; Boyle's "Sceptical Chymist" (1661) ; Newton's "Principia" (1687), selections, but at least the early chapters of Books 1 and 3 ; John Ray's "The Wisdom of God" (1691) ; James Hutton's "A Theory of the Earth" (1785), or possibly selected parts of Lyell's "Principles of Geology" ; Darwin's "Origin of Species" (1859) ; Einstein's "The Theory of Relativity" (1926). All university students, whatever their faculty, should be required to read these books and to take an examination on them at the end of the first term of their final year.

Such a course of reading would not be intended to make science students philosophical, nor to introduce them to the philosophy of science. It would give them real contact with greatness, such as the classic student has in reading Aeschylus or the philosophy student in reading Kant.

There is no question here of 'broadening' the scientist, of providing a humanist background for his studies. Nor is this proposal intended to provide the arts student with an outline of modern science or a 'potted' history of science. The way in which the scientist, and even the ordinary non-scientist, regards the physical universe has been largely determined by these works or the movements they epitomize; to think as we do and yet be ignorant of them is like being ignorant of the teachings of the New Testament while living in a Christian society.

Most of these are very old books, and much of their matter is long out of date. It would therefore be necessary to explain to what degree the facts and theories given in these works are still accepted, and how far they have been modified or discarded. It would also be necessary to make it plain to the students precisely why these works are important. This would mean putting each in its context, describing the state of each particular science before the work in question, the revolution affected by it, and its influence and importance in later scientific thought. This could be done in a course of lectures; but Tester believes this could be better done in a book prepared by experts in the several fields.

\section{ECOLOGICAL ANALYSIS OF THE INTERBREEDING OF CRESTED TITMICE IN TEXAS}

$\mathrm{E}$ COLOGY and behaviour during the early phases of the nesting cycles have been compared by Keith L. Dixon in two superficially distinct forms of titmice. A grey-crested bird, the tufted titmouse (Parus bicolor), is a characteristic inhabitant of deciduous forests of the humid eastern United States. Its distributional-range meets that of the blackcrested titmouse (Parus atricristatus) at a few points in central Texas. The latter bird is found commonly in openly spaced plant associations of arid northeastern Mexico and adjacent parts of Texas. Interbreeding occurs wherever populations of these nonmigratory forms are in contact.

Field work in central and western Texas was carried out during February-April 1951 and in January and February 1952. Each of the forms was studied first in areas remote from any influence of the other form; this study was used as a basis for evaluating conditions in areas where interbreeding was known to occur (University of California Publications in Zoology, 54, No. 3).

Tufted and black-crested titmice are similar in their habitat relations, especially in nesting requirements and foraging. The preferred habitats of these birds merge at the points of contact which lie in a transition from humid to arid climates. The call notes of the western form seemed louder and more nasal, and the songs were of longer duration. The only difference in display was the more erect carriage of the crest in the black-crested form. As the nesting cycle advanced, tufted titmice tended to be more secretive, whereas black-crested pairs were not so difficult to locate. Defence of territory appears more vigorous in the tufted titmouse. These differences in behaviour are more apparent later in the breeding cycle than they are at the time when pair formation is believed to occur. Detailed studies in the field, correlated with examination of specimens, suggests that mate selection is random where the populations overlap. No evidence of reduction in the vitality of birds of intermediate character was found. The evidence suggests that these two varieties diverged from a common ancestor, but that the changes which developed were not accompanied by the evolution of mechanisms which would ensure reproductive isolation. Since free interbreeding between black-crested and tufted titmice occurs, Dixon suggests that they should be considered conspecific.

The three principal areas where contacts between populations of the two kinds of titmice exist or have existed wore studied. In each area the junction was permitted by extension of woodland vegetation across prairies otherwise uninhabitable by these titmice. The upland timber of these areas is controlled by factors operating through the soil. This fact points to the permanence of the distributional relations, and the suggestion is made that the interbreeding of these titmice antedates the environmental disturbances brought about by the settlement of 'Texas by the white man.

The genetic constitution of one intermediate population, near the Aransas River, is shown to have changed towards that of the black-crested during the past century. The spread of woody vegetation is believed to have favoured the increase in numbers of titmice of the black-crested type in this area, and hence to have permitted increases in frequency of its genes in the intermediate population, while the contribution from the grey-crested populations was being reduced.

\section{STANFORD RESEARCH INSTITUTE, CALIFORNIA}

\section{REPORT FOR 1955}

$T$ HE report of operations for 1955 of the Stanford Research Institute, California*, records an increase in staff from 914 to 1,163 , of whom 630 have technical training and $125 \mathrm{Ph} . \mathrm{D}$. degrees. Contract research is being conducted at the rate of 10 million dollars a year, and in the nine years of the Institute's

* Stanford Research Institute. Report of Operations, 1955. Pp. 47. (Menlo Park, Calif.: Stanford Research Institute, 1956.) 